\title{
Efficacy and Safety of Telbivudine in Chronic Hepatitis B Treatment Throughout the Entire Pregnancy
}

\author{
Gebe Kadınlarda Tüm Gebelik Dönemi Boyunca Kronik Hepatit B Tedavisinde Telbivudinin \\ Etkinliği ve Güvenilirliği
}

\author{
Birol BAYSAL1', Şafak KAYA2 ${ }^{2}$ Selçuk AKSÖZ3, Şenol ÇOMOĞLU4, Mehmet ÇABALAK5 , Eyüp \\ ARSLAN6, Habibe ÇOLAK6, Nuran AKMIRZA5 ${ }^{5}$, Recep TEKIN7 , PInar TANTEKIN8
}

\begin{abstract}
'Bezmialem University Faculty of Medicine, Department of Gastroenterology, Istanbul, Turkey
${ }^{2}$ Gazi Yaşargil Training and Research Hospital, Clinic of Infectious Diseases, Diyarbakı, Turkey

${ }^{3}$ Adıyaman Training and Research Hospital, Clinic of Infectious Diseases, Adıyaman, Turkey

${ }^{4}$ Ümranive Training and Research Hospital, Clinic of Infectious Diseases, Istanbul, Turkey

${ }_{5}^{5}$ Şehit Kamil State Hospital, Clinic of Infectious Diseases, Gaziantep, Turkey

${ }^{6}$ Selahaddin Eyyübi State Hospital, Clinic of Infectious Diseases, Diyarbakır, Turkey

${ }^{7}$ Dicle University Faculty of Medicine, Department of Infectious Diseases, Diyarbakır, Turkey

${ }^{8}$ Özel Genesis Hospital, Clinic of Obstetrics and Gynecology, Diyarbakır, Turkey
\end{abstract}

\begin{abstract}
Objective: Women of childbearing potential treated for chronic hepatitis $B$ virus (HBV) infection may experience exacerbations during or after pregnancy. Infants may also acquire HBV infection through perinatal route. Currently, there is no antiviral agent approved for use in pregnancy. This makes it difficult to decide whether treatment should be withdrawn immediately or continued in women who become pregnant while on HBV antiviral therapy. The present study aims to establish the safety and, as a second measure, the efficacy of telbivudine in patients who became pregnant while they were on telbivudine treatment for chronic HBV infections and were maintained on the treatment throughout pregnancy.

Materials and Methods: Between 2010 and 2013, twentyone patients, who became pregnant while receiving telbivudine treatment for chronic HBV infection and continued the treatment, were evaluated retrospectively.

Results: The mean age of the patients was $28.9 \pm 6.3$ years (range: 18-41 years). All patients were hepatitis B envelope antigen-negative. The mean pre-treatment hepatic activity index was 9.4 \pm 1.6 (range: 7-13), and fibrosis and serum HBV, DNA measurements were $3.2 \pm 0.8$ (range: $2-5$ ) and $3.5 \times 10^{5} \pm 2.8 \times 10^{5} \mathrm{IU} / \mathrm{mL}$, respectively. No drug-related side effects were seen in any of the patients. All infants had normal birth weights and no abnormalities were observed in any of them. At the end of week 28, none of the infants was hepatitis B surface antigen-positive.
\end{abstract}

Conclusion: The use of telbivudine from the first trimester of pregnancy appears to be safe both for the mother and fetus and

\section{$0 ̈ z$}

Amaç: Kronik hepatit B virüsü (HBV) nedeni ile takip edilen doğurganlık çağındaki kadın hastalarda kronik karaciğer hastalı̆̆ı gelişebilir, gebelik döneminde veya sonrasında alevlenmelere neden olabilir, bununla birlikte perinatal dönemde HBV bulaşı ile bebek infekte olabilir. Gebelik döneminde HBV enfeksiyonu için kullanımı onaylanmış bir antiviral ilaç yoktur. Bu nedenle, antiviral ilaç kullanırken gebe kalan kadınlarda tedaviyi sonlandırma ya da devam etme kararını vermek zordur. Bu çalışmada kronik HBV enfeksiyonu nedeniyle telbivudin tedavisi almakta iken gebe kalan ve tüm gebelik dönemi boyunca tedavi alan hastalarda telbivudinin ilk etapta güvenilirliğini daha sonra ise etkinliğini değerlendirmeyi amaçladık.

Gereç ve Yöntemler: 2010-2013 yılları arasında kronik HBV enfeksiyonu nedeniyle telbivudine tedavisi kullanırken gebe kalan ve tedaviye devam kararı verilen 21 hasta retrospektif olarak değerlendirildi. Tüm hastaların tedavi başlandığı andaki serum hepatit B yüzey antijeni, hepatit B zarf antijen, anti-HBe, HBV DNA, alanin aminotransferaz (ALT), aspartat aminotransferaz (AST) seviyeleri, hepatik aktivite indeksi ve fibrozis değerleri kaydedildi. Daha sonra hastaların gebelik başlangıcl, gebelik dönemi boyunca ve doğum sonrası 6 . aya kadar 3 'er ay ara ile serum hepatit $B$ yüzey antijeni, hepatit B zarf antijen, anti-HBe, HBV, DNA, ALT, AST seviyeleri ölçüldü.

Bulgular: Hastaların yaş ortalaması 28,9 9 6,3 (yaş aralığı: 18-41) idi. Tüm hastalar hepatit B zarf antijen negatif idi. Tedavi öncesi hepatik aktivite indeksi ortalama $9,4 \pm 1,6$ (yaş aralığı: 7-13), fibrozis $3,2 \pm 0,8$ (yaş aralığı: 2-5), serum HBV DNA düzeyi $3,5 \times 10^{5} \pm 2,8 \times 10^{5} \mathrm{IU} / \mathrm{mL}$ idi. 
to be efficient in preventing mother-to-child transmission of HBV infection. However, randomized, controlled studies involving a higher number of subjects are needed.

Keywords: Pregnancy, chronic hepatitis B, treatment, telbivudine
Hastaların hiçbirinde ilaca bağlı yan etki görülmedi. Infantların hepsi normal doğum ağırlığına sahipti ve hiçbirinde anomali saptanmadı. Ayrıca 28. haftanın sonunda infantların hiçbirinde hepatit B yüzey antijen pozitifliği mevcut değildi.

Sonuç: Telbivudinin gebeliğin ilk trimesterinden itibaren kullanımı, hem anne hem fetus açısından güvenli, anneden infanta HBV geçişini önlemede de etkin görünmektedir. Bununla birlikte hasta sayısının daha fazla olduğu randomize kontrollü çalışmalara intiyaç vardır.

Anahtar Kelimeler: Gebelik, kronik hepatit B, tedavi, telbivudin

\section{Introduction}

About 350-400 million people worldwide are hepatitis $B$ virus (HBV) carriers and about 1 million people die each year due to HBV-related complications (1). The prevalence of HBV infection varies by geographic region. Our country is in a intermediate-endemic area with a carrier rate of $2-10 \%$ (2). Transmission from mother to infant becomes a more important issue with increasing endemicity (3). Perinatal transmission is associated with a higher risk for chronic condition and occurrence of complications including cirrhosis and hepatic cancer (4). Therefore, it is important to prevent HBV transmission from mother to infant. Although pregnant women are screened for HBV and infants born to HBV-positive mothers are routinely vaccinated and given immunoglobulin, perinatal transmission may be an issue especially in pregnant women with a high level of viremia (5). Mothers may also experience exacerbations of chronic hepatitis B during or after pregnancy. Acute exacerbations of chronic HBV infection may have a severe course and may be associated with fatality rates of $20-30 \%(4,6)$. In pregnant women, who already started antiviral treatment, the treatment should be maintained if liver biopsy demonstrates advanced fibrosis as withdrawal of treatment may result in exacerbations (7).

There is currently no antiviral agent approved for the treatment of chronic HBV infection in pregnancy. This makes it difficult to decide whether the treatment should be discontinued or maintained in women who become pregnant while receiving an antiviral agent. The health of both the mother and infant should be taken into consideration when making this decision. The major concern for the fetus is drug exposure during embryogenesis, while the primary issue for the mother involves the risk of disease exacerbation and progression because treatment cannot be initiated or should be discontinued due to pregnancy. This effect on the health of the mother may also affect the health of the fetus and the lives of both the mother and the fetus may be compromised (8). Of the nucleoside and nucleotide analogues that are being widely used for chronic HBV infection, lamivudine, adefovir and entecavir are assigned to category $C$ and telbivudine and tenofovir category $B$ by the Food and Drug Administration (FDA) (8). Telbivudine is an oral nucleoside analogue and is one of the two agents that can be used in pregnancy. Clinical experience, however, is quite limited (9). There are a few studies in the literature on the efficacy and safety of its use particularly throughout the whole pregnancy. In the present study, we aimed to investigate the safety and, as a second measure, the efficacy of telbivudine in patients who became pregnant while they were on telbivudine treatment for chronic HBV infection and were maintained on the treatment throughout pregnancy.

\section{Materials and Methods}

This is a retrospective study performed with the participation of five hospitals from Turkey. A standard questionnaire was sent to each hospital participating in this study and the data were collected via a computerized database. Pregnant women receiving antiviral therapy and their partners were contacted with and, based on their prior treatment experiences, hepatitis B envelope antigen (HBeAg) status, HBV DNA values and fibrosis values with hepatic biopsy results, they were informed about the possible risks to the mother and the infant should the treatment is withdrawn or continued. Patients who were maintained on treatment underwent periodic checks by an obstetrician. Approval of the relevant ethics committee was received.

\section{Patients}

Medical files of 256 patients, who were examined for chronic HBV infection and received telbivudine treatment between 2010 and 2013, were reviewed. Twenty-one patients, who became pregnant while on telbivudine and decided to remain on treatment, were included in this study. The inclusion criteria were as follows;

1) The patient should have started telbivudine treatment before becoming pregnant and continued therapy throughout pregnancy,

2) Should have no other underlying condition,

3) Should be negative for human immunodeficiency virus, hepatitis $C$ virus and hepatitis $D$ virus. All patients were reviewed for toxoplasmosis, syphilis, rubella, herpes, and cytomegalovirus and, these diseases were excluded. All patients were given folic acid over the first trimester. Routine screening tests for phenylketonuria and hypothyroidism were also performed for all infants.

Data were retrieved by reviewing patient files retrospectively. Baseline serum HBsAg, $\mathrm{HBeAg}$, anti-HBe, HBV DNA, alanine aminotransferase (ALT), aspartate aminotransferase (AST) levels, hepatic activity index and fibrosis values were recorded for each patient. Further serum HBsAg, HBeAg, anti-HBe, HBV DNA, ALT, and AST measurements were performed at pregnancy onset, during and following pregnancy every 3 months up to post-natal month 6. In addition, all fetuses were monitored for abnormalities periodically throughout the intrauterine phase. To prevent chronic HBV infection, all infants were given $100 \mathrm{IU}$ of intramuscular 
hepatitis B immunoglobulin (HBIG, HyperHEP B solvent/detergent treated; Talecris Biotherapeutic, NC, United States) and $10 \mathrm{mcg}$ of intramuscular hepatitis B (Recombivax HB; Merck Sharp and Dohme, NJ, United States) vaccines according to the relevant guidelines. Further doses of hepatitis B vaccine, one at week 4 and another at week 24, were administered. At the end of week 28, all infants were evaluated for HBsAg, anti-HBs and HBV DNA. In addition, all infants were monitored for any abnormalities and growth retardation for one year.

\section{Laboratory Tests}

HBV DNA was quantified using the Roche COBAS Amplicor HBV monitor assay which has a low limit of detection (LLD) of 500 copies $/ \mathrm{mL}$ (Roche Molecular Diagnostics, Branchburg, NJ, United States). This assay was later replaced by the Roche COBAS TaqMan HBV test with a LLD of 50 copies $/ \mathrm{mL}$ (Roche Molecular Diagnostics). HBV serological markers were detected by enzyme-linked immunosorbent assay kits on an Advia Centaur XP chemiluminescence immunoassay instrument (Siemens, Germany) according to the manufacturer's instructions.

\section{Statistical Analysis}

Statistical analysis was performed using Statistical Package for Social Sciences 19 (Computer Resource Center, Chicago, IL, United States). Measurement data were expressed as mean \pm standard deviation.

\section{Results}

The mean age of the 21 patients who became pregnant while receiving telbivudine for chronic HBV infection was $28.9 \pm 6.3$ years (range: $18-41$ years). In 8 patients (38.1\%), at least one of the previous births was HBsAg-positive. All patients were HBeAg-negative. With pre-treatment measurements, hepatic activity index was $9.4 \pm 1.6$ (range: 7-13), fibrosis was $3.2 \pm 0.8$ (range: 2-5) and serum HBV DNA was $3.5 \times 10^{5} \pm 2.8 \times 10^{5} \mathrm{IU} / \mathrm{mL}$. ALT, AST, and HBV DNA values measured before treatment, at pregnancy onset and at later time points are provided in Table 1. None of the patients had abortion. Two of them developed urinary tract infection after the sixth month of pregnancy. None of them experienced drug-associated side effects. Triple screening test performed over the course of the pregnancy demonstrated risk for only one mother, with the test performed at month 4, for which amniocentesis was performed, revealing no pathology. All of the infants were of normal birth weight (2700-3800 g) and none had phenylketonuria, hypothyroidism or malformations. At the end of week 28, none of the infants were HBsAg-positive. Only two infants had anti-HBs $<100 \mathrm{mIU} / \mathrm{mL}$, while the remaining 19 infants had anti-HBs levels above $100 \mathrm{mlU} / \mathrm{L}$.

\section{Discussion}

The primary route of HBV transmission is via blood and skin and/ or mucosal exposure to bodily fluids, but HBV is also present in the amniotic fluid, breast milk, vaginal secretions and cord blood (10). Perinatal transmission of HBV may be associated with significant rates of chronic infection and complications related to this infection, including cirrhosis and hepatocellular cancer (8). The prevalence of chronic HBV in pregnant women is $0.6 \%$ in low endemic areas and over $20 \%$ in high endemic areas $(8,10)$. Studies from our country have reported HBsAg positivity rates of 2.1 to $12.3 \%$ among pregnant women $(11,12,13,14)$. A woman of childbearing age infected with chronic HBV infection may develop chronic hepatic disease (fibrosis and/or cirrhosis) and may experience exacerbations during and following pregnancy and, furthermore, the infant may be infected via HBV transmission during the perinatal period. There is no conclusive information on the potential problems due to antiviral therapy in early pregnancy. However, if a patient has advanced fibrosis or elevated ALT levels, it may become necessary following a risk-benefit assessment to initiate treatment and to maintain the therapy throughout pregnancy $(6,8,14)$. The FDA has defined risk categories regarding the use of medicines during pregnancy. Accordingly, telbivudine, an agent used in chronic HBV infection treatment, is included in the pregnancy category $B$ (15). There are several studies in the literature on the use of telbivudine during pregnancy. However, most of these reports concern patients treated with telbivudine during the second or third trimesters of pregnancy to prevent transmission of HBV from the mothers with high viral load to their infants $(16,17,18,19)$. To the best of our knowledge, there have been a very few reports on the safe use of telbivudine throughout the whole pregnancy, beginning from the first trimester $(9,20)$. Treatment is challenging in women of childbearing potential. Given the 48-week treatment duration, interferons may be considered as the first choice if pregnancy is not being planned for the near future in these women. Problems are being encountered when deciding whether oral antiviral treatment should be started in situations where the women intent to become pregnant soon, have advanced hepatic disease and treatment delay would be risky. In case oral antiviral treatment has been initiated, the increased risk of mortality for both the mother and the infant due to possible acute chronic HBV infection exacerbation if the treatment is withdrawn when the patient becomes pregnant, presents another challenge. The present study examined the safe use of telbivudine throughout the whole pregnancy beginning from the first trimester during which embryogenesis takes place. A total of 21 patients who became pregnant while receiving telbivudine were evaluated in the study. Benefit to risk ratio was discussed with each individual patient since they all had advanced hepatic disease. An obstetrician also participated in the monitoring of patients who were maintained on

Table 1. Maternal laboratory investigation outcome

\begin{tabular}{|l|l|l|l|l|l|}
\hline Maternal outcomes & $\begin{array}{l}\text { Pre-treatment } \\
\text { period }\end{array}$ & The beginning of pregnancy & 6 th month of pregnancy & Postpartum 3rd month & $\begin{array}{l}\text { Postpartum 6 } \\
\text { month }\end{array}$ \\
\hline HBV DNA, (IU/mL) & $3.5 \times 10^{5}$ & Negative & Negative & Negative & Negative \\
\hline ALT, (IU/L) & 46.1 & 30.9 & 28.6 & 25.7 & 26.7 \\
\hline AST, (IU/L) & 40.7 & 27.7 & 24 & 22.9 & 21.9 \\
\hline HBV: Hepatitis B virus, ALT: Alanine aminotransferase, AST: Aspartate aminotransferase & \\
\hline
\end{tabular}


treatment. The mothers did not develop hepatic disease exacerbations throughout pregnancy and over the postpartum period and no side effects were observed. Congenital abnormalities were not observed in infants of the mothers treated with telbivudine. Maternal HBV transmission did not occur.

\section{Conclusion}

In conclusion, the use of telbivudine since the first trimester of pregnancy appears to be safe both for the mother and fetus and efficient in preventing HBV transmission from the mother to the infant. However, randomized, controlled studies involving a higher number of subjects are needed.

\section{Ethics}

Peer-review: Internal peer-reviewed.

\section{Authorship Contributions}

Surgical and Medical Practices: Şafak Kaya, Selçuk Aksöz, Mehmet Cabalak, Eyüp Arslan, Şenol Comoğlu, Pınar Tantekin, Concept: Birol Baysal, Şafak Kaya, Design: Habibe Çolak, Recep Tekin, Data Collection or Processing: Birol Baysal, Şafak Kaya, Analysis or Interpretation: Birol Baysal, Şafak Kaya, Literature Search: Nuran Akmirza, Birol Baysal, Şafak Kaya, Writing: Birol Baysal, Şafak Kaya

Conflict of Interest: No conflict of interest was declared by the authors.

Financial Disclosure: The authors declared that this study received no financial support.

Baysal B, Kaya Ş, Aksöz S, Comoğlu S, Cabalak M, Arslan E, Colak H, Akmirza N, Tekin R, Tantekin P. Efficacy and Safety of Telbivudine in Chronic Hepatitis B Treatment Throughout the Entire Pregnancy. Viral Hepatitis J 2016;22:10-13.

\section{References}

1. Dienstag JL. Chronic Viral Hepatitis. In: Mandell GL, Bennett JE, Dolin R (eds). Mandell, Douglas, and Bennett's Principles and Practise of Infectious Diseases. 6th ed. Philadelphia: Churchill Livingstone; 2005; p.1441-1464.

2. Demir I, Kaya S, Demirci M, Arıdoğan BC. Investigation of seropositivity of hepatitis B virus in healthworkers in Isparta, Turkey. Turkish J of Infect. 2006;20:183-187.

3. Jonas MM. Hepatitis B and pregnancy: an underestimated issue. Liver Int. 2009;29(Suppl 1):133-139.

4. Yogeswaran K, Fung SK. Chronic hepatitis B in pregnancy: unique challenges and opportunities. Korean $\mathrm{J}$ Hepatol. 2011;17:1-8.
5. Pan CQ, Duan ZP, Bhamidimarri KR, Zou HB, Liang XF, Li J, Tong MJ. An algorithm for risk assessment and intervention of mother to child transmission of hepatitis B virus. Clin Gastroenterol Hepatol. 2012;10:452-459.

6. Degli Esposti S, Shah D. Hepatitis B in pregnancy: challenges and treatment. Gastroenterol Clin North Am. 2011;40:355-372.

7. Bzowej NH. Optimal management of the hepatitis B patien who desires pregnancy or is pregnant. Curr Hepat Rep. 2012;11:82-89.

8. Petersen J. HBV treatment and pregnancy. J Hepat. 2011;55:1171-1173.

9. Mohan AT, Hariharan M. Efficacy and safety of telbivudine during pregnancy in a patient with $\mathrm{HBeAg}$-Negative chronic Hepatitis B. Hep B Annual. 2009;6:157-162.

10. Petrova M, Kamburov V. Breastfeeding and chronic HBV infection: clinical and social implications. World J Gastroenterol. 2010;16:5042-5046

11. Karaca C, Karaca N, Usta T. The incidence of hepatitis $B, C$ $D$ virus infection in pregnant population and rate of perinatal transmission of the hepatitis C virus. Turkish Academic J Gastroenterol. 2003;2:122-124.

12. Kölgeliler S, Demir LS, Demir NA, Özçimen S, Tabak S. Seropositivity of HBsAg and anti-HCV in Pregnant Women in Adıyaman. Viral Hepat J. 2012;18:98-101.

13. Madendag Y, Madendag IC, Celen S, Unlu S, Danışman N. Seroprevalence of hepatitis $B$, hepatitis $C$ and HIV at whole obstetric and gynecologic patients who applıed our hospital. Turkiye Klinikleri Clinical J Gynecol Obst. 2007;17:442-446.

14. Borgia G, Carleo MA, Gaeta GB, Gentile I. Hepatitis B in pregnancy. World J Gastroenterol. 2012;18:4677-4683.

15. Tran TT. Management of hepatitis B in pregnancy: weighing the options. Cleve Clin J Med. 2009;76(Suppl 3):25-29.

16. Liu MH, Sheng YJ, Liu JY, Hu HD, Zhang OF, Ren H. Efficacy of telbivudine on interruption of hepatitis B virus vertical transmission: a meta-analysis. Ann Saudi Med. 2013;33:169176.

17. Deng M, Zhou X, Gao S, Yang SG, Wang B, Chen HZ, Ruan $B$. The effects of telbivudine in late pregnancy to prevent intrauterine transmission of the hepatitis B virus: a systematic review and meta-analysis. Virol J. 2012;9:185.

18. Pan CQ, Han GR, Jiang HX, Zhao W, Cao MK, Wang CM, Yue $\mathrm{X}$, Wang GJ. Telbivudine prevents vertical transmission from $\mathrm{HBeAg}$-positive women with chronic hepatitis B. Clin Gastroenterol Hepatol. 2012;10:520-526.

19. Wu $Q$, Huang $H$, Sun $X$, Pan M, He Y, Tan S, Zeng $Y$, Li L, Deng G, Yan Z, He D, Li J, Wang Y. Telbivudine prevents vertical transmission of hepatitis B virus from women high viral loads: a prospective long-term study. Clin Gastroenterol Hepatol. 2015:13:1170-1176.

20. Liu M, Cai $H$, Yi W. Safety of telbivudine treatment for chronic hepatitis B for the entire pregnancy. J Viral Hepat. 2013;20(Suppl 1):65-70. 